\title{
Mukaiyama Aldol Reaction Catalyzed by Gallium(III) Triflate
}

\section{Key words}

\section{gallium}

Mukaiyama aldol reaction

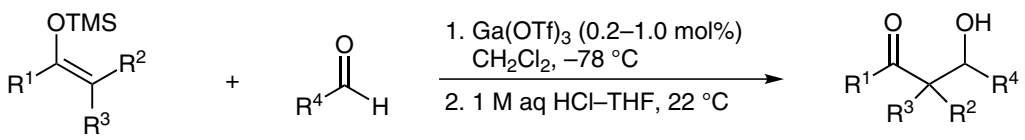

\section{Lewis acids}

Selected examples:<smiles>CC(C(=O)c1ccccc1)C(O)c1ccccc1</smiles>

$80 \%$ yield syn/anti $=85: 15$ $90 \%$ yield syn/anti $=70: 30$ $\mathrm{Ga}(\mathrm{OTf})_{3}(0.01 \mathrm{~mol} \%)$<smiles>CC(C(=O)c1ccccc1)C(O)/C=C/c1ccccc1</smiles>

$66 \%$ yield syn/anti $=82: 18$<smiles>Cc1ccc(C(O)C(C)C(=O)c2ccccc2)cc1</smiles>

$76 \%$ yield $76 \%$ yield
syn/anti $=80: 20$<smiles>CC(C(=O)c1ccccc1)C(O)C(C)(C)C</smiles>

$46 \%$ yield syn/anti $=96: 4$<smiles>CC(C(=O)c1ccccc1)C(O)c1ccccc1Br</smiles>

$76 \%$ yield syn/anti $=18: 82$<smiles>CC(C(=O)c1ccccc1)C(O)c1ccco1</smiles>

$56 \%$ yield syn/anti $=87: 13$
Significance: The authors report a mild method for the diastereoselective Mukaiyama aldol reaction. The process is catalyzed by gallium(III) triflate yielding to the corresponding $\beta$-hydroxy ketones in up to $92 \%$ yield.
Comment: The developed method is an efficient aldol reaction under mild conditions with a very low catalyst loading of gallium(III) triflate (0.01-1.0 mol\%). This is the first example of a metal triflate acting as a safe and stable slow-releasing source of triflic acid in the Mukaiyama aldol reaction. Gallium(III) triflate is a stable, easy-to-handle white solid. 